\title{
"The effects of industry characteristics on stock price synchronicity around IFRS adoption"
}

\begin{tabular}{|c|c|}
\hline AUTHORS & Hyejeong Shin ID https://orcid.org/0000-0001-7379-3740 \\
\hline ARTICLE INFO & $\begin{array}{l}\text { Hyejeong Shin (2019). The effects of industry characteristics on stock price } \\
\text { synchronicity around IFRS adoption. Investment Management and Financial } \\
\text { Innovations, 16(1), 89-99. doi:10.21511/imfi.16(1).2019.07 }\end{array}$ \\
\hline DOI & http://dx.doi.org/10.21511/imfi.16(1).2019.07 \\
\hline RELEASED ON & Monday, 11 February 2019 \\
\hline RECEIVED ON & Thursday, 18 October 2018 \\
\hline ACCEPTED ON & Wednesday, 23 January 2019 \\
\hline LICENSE & $\begin{array}{l}(\mathrm{cc}) \mathrm{EY} \\
\text { This work is licensed under a Creative Commons Attribution } 4.0 \text { International } \\
\text { License }\end{array}$ \\
\hline JOURNAL & "Investment Management and Financial Innovations" \\
\hline ISSN PRINT & $1810-4967$ \\
\hline ISSN ONLINE & $1812-9358$ \\
\hline PUBLISHER & LLC "Consulting Publishing Company "Business Perspectives" \\
\hline FOUNDER & LLC "Consulting Publishing Company "Business Perspectives" \\
\hline
\end{tabular}

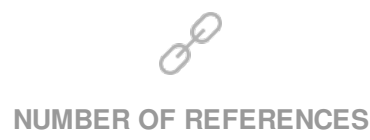

28

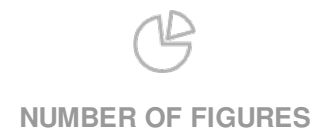

0

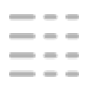

NUMBER OF TABLES

5

(C) The author(s) 2022. This publication is an open access article. 


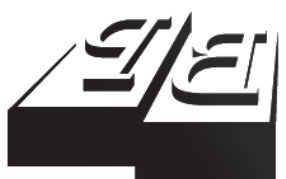

BUSINESS PERSPECTIVES

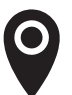

LLC "CPC "Business Perspectives" Hryhorii Skovoroda lane, 10, Sumy, 40022, Ukraine

www.businessperspectives.org

Received on: $18^{\text {th }}$ of October, 2018 Accepted on: $23^{\text {rd }}$ of January, 2019

(C) Hyejeong Shin, 2019

Hyejeong Shin, Ph.D., Assistant Professor, College of Economics \& Business Administration, Kyonggi University, South Korea.

\section{(ㄷ) (i)}

This is an Open Access article, distributed under the terms of the Creative Commons Attribution 4.0 International license, which permits unrestricted re-use, distribution, and reproduction in any medium, provided the original work is properly cited.

\begin{abstract}
The purpose of this paper is to investigate whether a change in stock price synchronicity after IFRS adoption differs by industry characteristics. IFRS adoption was expected to improve earnings quality and comparability. Industry concentration and homogeneity are utilized as industry characteristics, which are known as determinants to earnings quality and comparability to examine IFRS adoption effect on the synchronicity.

Using Korean firms listed from 2006 to 2015, the author found that stock price synchronicity decreases after IFRS adoption. The reduction in synchronicity is larger for firms in a concentrated industry. However, the researcher didn't find that incremental effect of homogeneity on synchronicity changes around IFRS adoption. These results remain unchanged after several robustness tests. The results imply that earnings quality after IFRS adoption improves, while comparability effect is not evident in the Korean market.

The paper has implications that co-movement of stock price decreases after IFRS adoption in that delivering firm-specific information to investors; in addition, the magnitude of impacts of IFRS adoption differs by the industry characteristics. The author extends prior studies about IFRS adoption effect on the capital market by providing that the effects need to be examined after considering the industry characteristics.
\end{abstract}

Keywords

JEL Classification

\title{
INTRODUCTION
}

It is investigated whether the impact of the mandatory adoption of International Financial Reporting Standards (IFRS) on stock price synchronicity differs by industry characteristics.

IFRS adoption requires firms to deliver information regarding their intrinsic value by demanding more disclosure and allowing firms a broader range of accounting policies (Schipper, 2005; Barth, 2006). This accounting regime change is expected to enable investors to capitalize firms' idiosyncratic information into stock price. In line with this perspective, prior studies show that an increase in firm-specific information attributes to a reduction in stock price synchronicity (Kim \& Shi, 2012; Shin \& Choi, 2013; Beuselinck et al., 2009). They insist that a decrease in synchronicity after IFRS adoption is the evidence of earnings quality improvement.

Given that the high synchronicity implies that firms' reported earnings are in a situation in which the market's reliance on industry-wide information is greater (Morck et al., 2000; Ferreira \& Laux, 2007; Piotroski \& Roulstone, 2004), or the comparability among firms is higher (Bissessur \& Hodgson, 2012, Peterson et al., 2015), the effect of 
IFRS on synchronicity has been investigated. Recently, Bissessur and Hodgson (2012) provide another view on synchronicity changes after IFRS adoption. They argue that enhanced comparability can increase synchronicity rather than decrease it. In addition, they show that IFRS adoption impacts stock price synchronicity differently across industries according to each industry's demand elasticity to industry-wide information. That is, the extent to which investors incorporate firmspecific information into stock prices is affected by the industry's elasticity in the pre-adoption period. Their study implies that the IFRS adoption effect is different depending on the industry characteristics.

Motivated by their work, the author investigates the role of industry characteristics on the decrease in synchronicity around IFRS adoption. Specifically, he focuses on market concentration and homogeneity as industry characteristics, because they are associated with earnings quality and comparability, respectively.

Extant studies suggest that industry competition plays a role in market governance so that earnings quality is higher (lower) for firms in a competitive (concentrated) industry (Ali et al., 2014; Dhaliwal et al., 2014). If earnings quality is improved after IFRS adoption, the synchronicity is reduced after adoption. Considering that IFRS adoption effect is larger for firms with low earnings quality and severe information asymmetry in the pre-adoption period, it is expected that the synchronicity reduction after IFRS adoption will be greater for firms in the concentrated industry.

As another industry feature, industry homogeneity shows how the profitability of firms in the same industry is fundamentally correlated and how the ways firms map economic events into accounting earnings are similar to each other (De Franco et al., 2011). As homogeneity increases, comparability increases (Wang \& Wu, 2015) and enhanced comparability leads to high synchronicity (Peterson et al., 2015). Therefore, if comparability increases after IFRS adoption, stock price synchronicity increases after adoption. Because comparability increase effects are larger for firms in less homogeneous industries in the pre-adoption period, stock price synchronicity increases are more pronounced for less homogeneous industries.

It is examined whether the synchronicity reduction after IFRS adoption is larger for firms in concentrated industries (i.e. the earnings quality effect) and smaller for firms in more homogeneous industries (i.e. the comparability effect).

Using firms listed on the Korean Stock Exchange (KSE) from 2006 to 2015, the author finds that synchronicity decreases in the post-IFRS adoption period are greater in more concentrated industries. However, homogeneity does not have an additional impact on a decrease in synchronicity after IFRS adoption.

The results have implications that the co-movement of stock price decreases after IFRS adoption differs according to the industry concentration, supporting the earnings quality hypothesis. The author believes that the comparability hypothesis is not supported, because firms change their accounting policies after IFRS adoption, leading to a change in the homogeneity.

This paper is important in that the author focuses on industry structure, while prior studies on IFRS adoption primarily focus on individual firm's characteristics such as analyst following and institutional investor ownership (Kim \& Shi, 2012). Although industry characteristics are associated with firms' earnings quality (Dechow et al., 2010), to the best of his knowledge, few studies examine whether stock price synchronicity varies according to industry characteristics explicitly. By incorporating industry characteristics, the author extends the literature on stock price synchronicity and the impact of IFRS adoption. 
In addition, the author provides evidence that the earnings quality effect is more pronounced than the comparability effect in the Korean market, even though stock price synchronicity decreases on average after IFRS adoption.

This paper consists of 6 sections. The author introduces our research motivation in the Introduction section and reviews the prior studies and develops the hypotheses in section 1 . He proposes the research model in section 2 and provides the analysis results in section 3. Lastly, the author summarizes the results and presents the study's conclusions in the last section.

\section{PRIOR RESEARCH AND HYPOTHESES DEVELOPMENT}

IFRS adoption is a historical accounting regime change that affects the information environment drastically. Firms are required to disclose more relevant information to investors, and management has more discretion in the accounting practices under IFRS. Many researchers investigate whether earnings quality increases after IFRS adoption. They provide empirical evidence that transparency of accounting information increases (Schipper, 2005) and earnings smoothing decreases (Ha et al., 2016) after the adoption. In addition, earnings reported under IFRS are likely to be more relevant to investors, because IFRS allows managements' discretion on accounting policies such as fair value accounting (Barth, 2006) and consequently leads to lower cost of capital (Daske et al., 2013; Kim \& Shi, 2012). These findings suggest that earnings quality in terms of firm-specific information increases after IFRS adoption (Horton et al., 2013; Kim \& Shi, 2012).

Another benefit of IFRS adoption is an increase in accounting information comparability (IASB, 2010). When comparability increases, investors are more likely to utilize other firms' information to interpret focal firms' earnings (Barth, 2008). Brochet et al. (2013), trying to disentangle the earnings quality effect and comparability effect, provide that the capital market benefits more from enhanced comparability than firm-specific earnings disclosure.

These two benefits of IFRS adoption can affect stock price synchronicity differently. After IFRS adoption, firms are required to disclose more firm-specific information, synchronicity is expected to decrease after IFRS adoption. However, it is also possible that stock price synchronicity increases under IFRS if the comparability is enhanced due to harmonization of accounting practices.

Many studies on how synchronicity changes around IFRS adoption support the improvement in earnings quality (Kim \& Shi, 2012; Beuselinck et al., 2009) Using Korean data, Shin and Choi (2013) also find a decrease in synchronicity after IFRS adoption, and this reduction is more pronounced for firms with low synchronicity before the adoption.

However, using Australian firms, Bissessur and Hodgson (2012) show that market experiences an instant drop at the year of IFRS adoption and increase in synchronicity afterward. In addition, such a pattern in synchronicity changes is not consistently observed across all industries. They suggest that the synchronicity changes around IFRS adoption differ by the level of synchronicity before the adoption and that demand elasticity is one of the determinants of synchronicity. Because industry elasticity is associated with investors' weighing of firm-specific and industry-wide information, the synchronicity changes around IFRS adoption differ by industry.

Firms in the concentrated industry are reluctant to disclose firm-specific information (Ali et al., 2014; Dhaliwal et al., 2014; Yen et al., 2016). Therefore, investors tend to rely on industry-wide information rather than firm-specific information, resulting in high synchronicity (Piotroski \& Roulstone, 2004). Considering that the IFRS adoption effect is larger for firms with low earnings quality and severe information asymmetry before the adoption (Shin \& Choi, 2013), this leads to expect that the earnings quality effect on synchronicity (i.e. reduced synchronicity) is more pronounced for firms in a concentrated industry. Thus, the first hypothesis on the earnings quality effect on synchronicity is as follows: 
H1: After IFRS adoption, synchronicity decreases for firms in a more concentrated industry.

Investors can easily compare firms and identify the similarities and differences when firms apply common accounting practices in the earnings-generating process. Firms that belong to the same industry face the same economic events, and when their way of mapping these events to their accounting earnings is similar, the comparability increases (De Franco et al., 2011).

Piotroski and Roulstone (2004) suggest that synchronicity is larger when the profitability of firms in the same industry is correlated with industry average performance. Peterson et al. (2015) also analyze the relationship between accounting homogeneity and stock price synchronicity, suggesting the higher synchronicity in more homogeneous firms. These studies argue that because information transfer is stronger for firms whose accounting policy is correlated with the industry average accounting policy, the synchronicity is larger for firms that apply a similar accounting policy to their peer firms. That is, investors are more likely to utilize common industrywide information for their valuation when enhanced comparability leads to the variance of firm-specific information (Dye \& Sridhar, 2004). The above papers imply that accounting comparability increases after IFRS adoption (DeFond et al., 2011) and is likely to increase synchronicity instead of decreasing it.

The author posits that if accounting homogeneity is associated with enhanced comparability and higher synchronicity (Peterson et al., 2015; Bissessur \& Hodgson, 2012), the synchronicity would increase after IFRS adoption for firms in less homogeneous industries. The second hypothesis, therefore, is proposed as follows:

H2: After IFRS adoption, synchronicity increases for firms in a less homogeneous industry.

\section{RESEARCH METHOD}

\subsection{Sample selection}

The sample consists of stock listed on the Korea Stock Exchange from 2006 to 2015. The author excludes firms in the financial industry and those with fiscal years that end in a month other than December. The financial data and stock price data for the Korean stock market and US market are from the Fn-Guide database. The author deletes firms from the observations if the data required to measure variables are not available. In addition, the researcher excludes firms that voluntarily adopted IFRS in 2009-2010 to mitigate the impact on the analysis results (Leuz \& Wysocki, 2016). Because the author investigate the effects of industry characteristics on synchronicity, industries that have one firm within the industry (i.e. monopoly) are excluded from the sample. Homogeneity is measured as the correlations of firms such that it is not possible to average the correlation with industry having only one firm. The final sample contains 4,997 firm-year observations.

\subsection{Research model}

The author develops a research model to test our hypotheses.

$$
\begin{aligned}
& S Y N C H_{i, t}=\beta_{0}+\beta_{1} I N D_{i, t}+\beta_{2} I N D_{i, t} \cdot \operatorname{IFRS}_{i, t}+ \\
& +\beta_{3} \operatorname{IFRS}_{i, t}+\beta_{4} \operatorname{SIZE}_{i, t}+\beta_{0} T B Q L_{i, t}+ \\
& +\beta_{6} L E V_{i, t}+\beta_{7} V O L_{i, t}+\beta_{8} \text { BETA }_{i, t}+ \\
& +\beta_{9} \text { STDROA }_{i, t}+\beta_{10} \text { FOR }_{i, t}+\beta_{11} \text { MTB }_{i, t}+ \\
& +\beta_{12} \operatorname{TRADING}_{i, t}+\beta_{13} P N_{i, t}+\text { year }+\varepsilon_{i, t},
\end{aligned}
$$

where SYNCH - synchronicity of firm-level stock returns with market-wide, industry-level, and U.S. stock market returns as calculated in the model (1), IND - industry characteristic, which is industry concentration or industry homogeneity, $C O N$ - decile of industry concentration calculated as sales-based Herfindahl-Hirschman index, $H G N$ - industry homogeneity calculated as the mean value of correlation coefficients of the annual percentage change in operating expenses for all companies in the same industry from 2006 to $2015, I F R S$ - dummy variable equal 1 if $I F R S$ adoption period, and 0 otherwise, SIZE - firm size measured as $\ln ($ market value), $T B Q L$ lagged Tobin's $q, L E V$ - leverage of total liability/ total asset, $V O L$ - annualized stock return volatility calculated as $\ln$ ( standard deviation of the weekly returns ${ }^{*}$ squared root of trading days per year), BETA - stock beta, STDROA - standard deviation of $R O A$ measured over the previous 
five years, FOR - foreign investors' shareholding ratio, $M T B$ - market value to book value of equity, TRADING - trading volume divided by outstanding shares, $P N$ - industry size measured as $\ln$ (number of firms within the industry), year - year dummies.

To control for the impact of outliers in the test, the continuous variables are winsorized at 1 percent and 99 percent. Industry clustered standard errors were used to control for other industry effects other than industry concentration and homogeneity.

\subsection{Variable measurement}

\subsubsection{Stock price synchronicity}

Stock return synchronicity measured as $R^{2}$ reflects the extent of market and industry information incorporated into a firm' stock price. Under the CAPM, firm's expected returns is a linear function of expected market return, indicating that market returns are an important indicator of the empirical validity of the Capital Asset Price Model (CAPM) (Roll, 1988). Since Durnev et al. (2003), Piotroski and Roulstone (2004) developed and provided the synchronicity model based on the asset pricing models, many studies have used the $R^{2}$ to measure the synchronicity, the extent of firm-specific information capitalized into firm's stock price.

To be specific, similar to the previous research (Kim \& Shi, 2012; Shin \& Choi, 2013), the synchronicity of each firm-year is measured using the $\mathrm{R}$-square of the market model. Using equation (2), the author regresses each firm's market returns on the current and prior period's value-weighted market return (MKTRET) and the current and prior period's value-weighted industry return (INDRET). In addition, the Korean stock market is influenced by the U.S stock market, stock returns of the U.S. market were included in the current and prior period. Firms that have less than 40 weekly return observations for each firm in each year are excluded.

$$
\begin{aligned}
& \operatorname{RET}_{i, t}=\gamma_{0}+\gamma_{1} \operatorname{MKTRET}_{i, t-1}+\gamma_{2} \operatorname{MKTRET}_{i, t}+ \\
& +\gamma_{3} \operatorname{INDRET}_{i, t-1}+\gamma_{4} \operatorname{INDRET}_{i, t}+ \\
& +\gamma_{5} \operatorname{USRET}_{i, t-1}+\gamma_{6} \operatorname{USRET}_{i, t}+\varphi_{i, t} .
\end{aligned}
$$

We use the log-transformation for lognormal distribution of variables as equation (3).

$$
S Y N C H_{i, t}=\log \left(\frac{R_{i, t}^{2}}{1-R_{i, t}^{2}}\right) .
$$

\subsubsection{Independent variables measurement}

\section{Industry concentration}

The sales-based Herfindahl-Hirschman index is defined as a market concentration based on the two-digit Korea Standard Industry Classification (KSIC) code. Although the listed firms are used as the research sample, public and private firms we included when calculating the market concentration.

\section{Operating homogeneity}

Operating homogeneity was calculated as below according to Cairney and Young (2006) using listed firms, because IFRS is only required to be applied to listed firms.

First, measure operating expenses are measured for the research period 2006-2015. Operating expenses (OEX) are calculated as (Sales - Operating income + Depreciation and Amortization).

Next, changes in operating expenses were calculated as $\left[\left(O E X_{t}-O E X_{t-1}\right) / O E X_{t-1}\right]$ for each firm for each year. The correlations of changes in operating expenses of a firm with every other firm within the industry over the research period. After that step, the correlation by industry was summed and divided by the number of correlations to obtain the average correlation per industry. The average correlation per industry is used as the industry homogeneity variable $(H G N)$.

Industry homogeneity (HGN) is different from the fundamental correlation of the return on asset $(R O A)$ used in prior studies (e.g. Piotroski \& Roulstone, 2004). The fundamental correlation is each firm's profitability correlated with the industry average profitability, which is the firm-level measurement, while homogeneity is the average correlation of all firms within an industry, which is the industry level measurement. 
For control variables we consider firm size (SIZE), leverage $(L E V)$, Tobin's $q(T B Q L)$, market to book ratio $(M T B)$, foreign investor's share $(F O R)$, systemic risk of the market (BETA), volatility of firms' profitability (STDROA), volatility of stock returns (VOL), trading volume (TRADING), and the number of firm in the industry $(P N)$.

\section{RESULTS}

\subsection{Descriptive statistics}

Panel A in Table 1 shows the descriptive statistics of variables for pool sample, and Panel B is the mean comparison of variables between the preIFRS period and the post-IFRS period. SYNCH in post-IFRS is lower than before the pre-IFRS period; the synchronicity decreased after the adoption of IFRS.
The mean of SYNCH is $-1.272,-1.130$, and -1.395 for the pooled sample, pre-IFRS period, and postIFRS period, respectively. This shows that the synchronicity decrease observed following IFRS adoption is consistent with that of previous studies (Kim \& Shi, 2012; Bissessur \& Hodgson, 2012). Our variables of interest, industry concentration $(C O N)$ decreases, and homogeneity (HGN) increases, following IFRS adoption.

Among control variables, SIZE, TBQL, VOL, BETA, $M T B$ and FOR have significant differences between pre- and post-IFRS adoption. $L E V, S T D R O A$, and TRADING do not.

Table 2 shows the correlations of variables. Industry concentration $(C O N)$ is positively correlated with synchronicity (SYNCH), but homogeneity is not significantly correlated. This supports partially our expectation that as the industry is

Table 1. Descriptive statistics

\begin{tabular}{|c|c|c|c|c|}
\hline \multicolumn{5}{|c|}{ Panel A. Full sample $(n=4,997)$} \\
\hline Variables & Mean & Std. Dev. & Min & Max \\
\hline SYNCH & -1.272 & 1.325 & -5.321 & 1.449 \\
\hline CON & 0.175 & 0.145 & 0.031 & 0.974 \\
\hline HGN & 0.220 & 0.220 & -0.308 & 0.998 \\
\hline IFRS & 0.540 & 0.499 & 0.000 & 1.000 \\
\hline SIZE & 25.954 & 1.628 & 23.256 & 30.575 \\
\hline$T B Q L$ & 1.078 & 0.576 & 0.416 & 4.076 \\
\hline$L E V$ & 0.424 & 0.202 & 0.032 & 0.900 \\
\hline$V O L$ & 3.818 & 18.033 & 17.800 & 106.213 \\
\hline BETA & 0.776 & 0.387 & -0.054 & 1.706 \\
\hline STDROA & 0.042 & 0.059 & 0.002 & 0.412 \\
\hline$F O R$ & 0.103 & 0.137 & 0.000 & 0.652 \\
\hline MTB & 1.219 & 1.137 & 0.206 & 7.121 \\
\hline TRADING & 2.410 & 3.641 & 0.068 & 23.257 \\
\hline$P N$ & 3.871 & 0.850 & 1.099 & 5.560 \\
\hline
\end{tabular}

Panel B. Mean comparison by IFRS adoption

\begin{tabular}{|c|c|c|c|c|c|c|}
\hline \multirow{2}{*}{ Variables } & \multicolumn{2}{|c|}{$I F R S=0(n=2,303)$} & \multicolumn{2}{|c|}{$I F R S=1(n=2,694)$} & \multirow{2}{*}{$\begin{array}{c}\text { Mean } \\
\text { difference }\end{array}$} & \multirow{2}{*}{$t$-value } \\
\hline & Mean & Std. Dev. & Mean & Std. Dev. & & \\
\hline SYNCH & -1.130 & 1.274 & -1.395 & 1.357 & 0.265 & $7.071^{* * *}$ \\
\hline CON & 0.190 & 0.152 & 0.162 & 0.138 & 0.028 & $6.823^{* * *}$ \\
\hline$H G N$ & 0.150 & 0.133 & 0.281 & 0.259 & -0.131 & $-21.955^{* * *}$ \\
\hline SIZE & 25.782 & 1.641 & 26.102 & 1.602 & -0.319 & $-6.943^{* * *}$ \\
\hline$T B Q L$ & 1.063 & 0.551 & 1.091 & 0.596 & -0.028 & $-1.714^{*}$ \\
\hline$L E V$ & 0.428 & 0.189 & 0.422 & 0.212 & 0.006 & 1.090 \\
\hline$V O L$ & 3.907 & 0.334 & 3.742 & 0.369 & 0.165 & $16.481^{* * *}$ \\
\hline BETA & 0.817 & 0.365 & 0.741 & 0.401 & 0.077 & $7.016^{* * *}$ \\
\hline STDROA & 0.040 & 0.055 & 0.043 & 0.063 & -0.002 & -1.267 \\
\hline$F O R$ & 0.110 & 0.144 & 0.097 & 0.129 & 0.132 & $3.413 * * *$ \\
\hline MTB & 1.154 & 1.067 & 1.273 & 1.191 & -0.119 & $-3.698^{* * *}$ \\
\hline TRADING & 2.388 & 3.398 & 2.428 & 3.837 & -0.040 & -0.388 \\
\hline$P N$ & 3.802 & 0.819 & 3.930 & 0.872 & -0.128 & $-5.332^{* * *}$ \\
\hline
\end{tabular}

Notes: The definitions of variables are defined in model (1) except for CON. CON is the raw value of HHI instead of decile of HHI. The notations ${ }^{\star * \star},{ }^{* \star},{ }^{\star}$ represent $\mathrm{p}<0.01, \mathrm{p}<0.05$, and $\mathrm{p}<0.10$, respectively. 
Table 2. Correlations

\begin{tabular}{|c|c|c|c|c|c|c|c|c|c|c|c|c|c|}
\hline Variables & 1 & 2 & 3 & 4 & 5 & 6 & 7 & 8 & 9 & 10 & 11 & 12 & 13 \\
\hline 1. SYNCH & 1 & - & - & - & - & - & - & - & - & - & - & - & - \\
\hline \multirow{2}{*}{ 2. $\mathrm{CON}$} & 0.037 & 1 & - & - & - & - & - & - & - & - & - & - & - \\
\hline & $(0.009)$ & - & - & - & - & - & - & - & - & - & - & - & - \\
\hline \multirow{2}{*}{ 3. $H G N$} & 0.018 & -0.009 & 1 & - & - & - & - & - & - & - & - & - & - \\
\hline & $(0.216)$ & $(0.508)$ & - & - & - & - & - & - & - & - & - & - & - \\
\hline \multirow{2}{*}{ 4. IFRS } & -0.100 & -0.096 & 0.297 & 1 & - & - & - & - & - & - & - & - & - \\
\hline & $(0.000)$ & $(0.000)$ & $(0.000)$ & - & - & - & - & - & - & - & - & - & - \\
\hline \multirow{2}{*}{ 5. SIZE } & 0.235 & 0.104 & 0.068 & 0.098 & 1 & - & - & - & - & - & - & - & - \\
\hline & $(0.000)$ & $(0.000)$ & $(0.000)$ & $(0.000)$ & - & - & - & - & - & - & - & - & - \\
\hline \multirow{2}{*}{ 6. TBQL } & 0.062 & 0.082 & -0.022 & 0.024 & 0.383 & 1 & - & - & - & - & - & - & - \\
\hline & $(0.000)$ & $(0.000)$ & $(0.123)$ & $(0.087)$ & $(0.000)$ & - & - & - & - & - & - & - & - \\
\hline \multirow{2}{*}{ 7. $L E V$} & 0.076 & 0.045 & 0.074 & -0.015 & -0.030 & 0.036 & 1 & - & - & - & - & - & - \\
\hline & $(0.000)$ & $(0.002)$ & $(0.000)$ & $(0.276)$ & $(0.033)$ & $(0.011)$ & - & - & - & - & - & - & - \\
\hline \multirow{2}{*}{ 8. VOL } & 0.050 & -0.031 & -0.149 & -0.227 & -0.237 & 0.124 & 0.245 & 1 & - & - & - & - & - \\
\hline & $(0.000)$ & $(0.031)$ & $(0.000)$ & $(0.000)$ & $(0.000)$ & $(0.000)$ & $(0.000)$ & - & - & - & - & - & - \\
\hline \multirow{2}{*}{ 9. BETA } & 0.203 & 0.009 & -0.055 & -0.099 & 0.246 & 0.143 & 0.207 & 0.390 & 1 & - & - & - & - \\
\hline & $(0.000)$ & $(0.549)$ & $(0.000)$ & $(0.000)$ & $(0.000)$ & $(0.000)$ & $(0.000)$ & $(0.000)$ & - & - & - & - & - \\
\hline \multirow{2}{*}{ 10. STDROA } & -0.041 & 0.015 & -0.060 & 0.018 & -0.125 & 0.141 & 0.088 & 0.292 & 0.038 & 1 & - & - & - \\
\hline & $(0.004)$ & $(0.290)$ & $(0.000)$ & $(0.205)$ & $(0.000)$ & $(0.000)$ & $(0.000)$ & $(0.000)$ & $(0.007)$ & - & - & - & - \\
\hline \multirow{2}{*}{ 11. FOR } & 0.152 & 0.131 & -0.002 & -0.048 & 0.506 & 0.230 & -0.105 & -0.207 & 0.050 & -0.105 & 1 & - & - \\
\hline & $(0.000)$ & $(0.000)$ & $(0.907)$ & $(0.001)$ & $(0.000)$ & $(0.000)$ & $(0.000)$ & $(0.000)$ & $(0.000)$ & $(0.000)$ & - & - & - \\
\hline \multirow{2}{*}{ 12. MTB } & 0.010 & 0.061 & -0.013 & 0.052 & 0.389 & 0.731 & 0.114 & 0.176 & 0.097 & 0.195 & 0.176 & 1 & - \\
\hline & $(0.474)$ & $(0.000)$ & $(0.357)$ & $(0.000)$ & $(0.000)$ & $(0.000)$ & $(0.000)$ & $(0.000)$ & $(0.000)$ & $(0.000)$ & $(0.000)$ & - & - \\
\hline \multirow{2}{*}{ 13. TRADING } & -0.037 & 0.000 & -0.033 & 0.006 & -0211 & 0.055 & 0.121 & 0.622 & 0.229 & 0.195 & -0.179 & 0.143 & 1 \\
\hline & $(0.009)$ & $(0.993)$ & $(0.019)$ & $(0.698)$ & $(0.000)$ & $(0.000)$ & $(0.000)$ & $(0.000)$ & $(0.000)$ & $(0.000)$ & $(0.000)$ & $(0.000)$ & - \\
\hline \multirow{2}{*}{ 14. $P N$} & -0.040 & -0.256 & -0.117 & 0.122 & -0.105 & -0.079 & -0.100 & 0.070 & 0.125 & 0.043 & -0.103 & -0.814 & 0.092 \\
\hline & $(0.005)$ & $(0.000)$ & $(0.000)$ & $(0.000)$ & $(0.000)$ & $(0.000)$ & $(0.000)$ & $(0.000)$ & $(0.000)$ & $(0.000)$ & $(0.000)$ & $(0.000$ & $(0.000)$ \\
\hline
\end{tabular}

Note: The definitions of variables are defined in model (1). P-value is listed in parentheses below correlation coefficient estimates.

more concentrated, stock price incorporates industry-level information rather than firm-specific information. Additionally, the negative correlation between IFRS and SYNCH imply that synchronicity decreased after the adoption of IFRS.

\subsection{Regression results}

Table 3 shows the results for hypothesis 1 of the industry concentration and hypothesis 2 of the industry homogeneity. Because the high value of the industry characteristics (IND) means a more concentrated or a more homogeneous industry, to support the hypotheses, a negative coefficient for is expected IND $D^{\star} I F R S$ for both competition and homogeneity.

For industry concentration $(\mathrm{CON})$, the analysis results are as follows. According to the model (1) and the model (2) in Table 3, IND has a positive but insignificant coefficient, and IFRS has negative and insignificant. However, the variable of inter- est, IND ${ }^{\star} I F R S$, has a significant and negative value in the model (2).

These results imply that synchronicity decreases after IFRS adoption in the concentrated industry, which is supporting the hypothesis 1 .

For the test of industry homogeneity (HGN), the results in the model (3) show that IND is significantly positive and IFRS is significantly negative, which is consistent that the more fundamental earnings are correlated among industry peers, the synchronicity increases (Piotroski \& Roulstone, 2004). However, IND becomes insignificant although still positive when the interaction term is included in the regression as presented in the model (4). The post-IFRS adoption period, IFRS, has a significantly negative coefficient. This analysis shows that synchronicity decreases after IFRS adoption. However, the test variable of $I N D^{*} I F R S$ is not significant, rejecting the hypothesis 2 . 
Table 3. Test results for hypotheses

\begin{tabular}{|c|c|c|c|c|}
\hline \multirow{3}{*}{ Variables } & \multicolumn{2}{|c|}{$I N D=C O N$} & \multicolumn{2}{|c|}{$I N D=H G N$} \\
\hline & Model (1) & Model (2) & Model (3) & Model (4) \\
\hline & $\begin{array}{c}\text { Coeff. } \\
\text { (t-value) }\end{array}$ & $\begin{array}{c}\text { Coeff. } \\
(t \text {-value })\end{array}$ & $\begin{array}{c}\text { Coeff. } \\
(t \text {-value) }\end{array}$ & $\begin{array}{c}\text { Coeff. } \\
(t \text {-value })\end{array}$ \\
\hline \multirow{2}{*}{$I N D$} & -0.018 & -0.005 & 0.302 & 0.420 \\
\hline & $(-1.590)$ & $(-0.400)$ & $(1.999)^{*}$ & $(2.043)^{* *}$ \\
\hline \multirow{2}{*}{ IND*IFRS } & - & -0.024 & - & -0.173 \\
\hline & - & $(-2.700)^{* * *}$ & - & $(-0.766)$ \\
\hline \multirow{2}{*}{ IFRS } & -0.179 & -0.048 & -0.213 & -0.183 \\
\hline & $(-2.840) * * *$ & $(-0.615)$ & $(-3.254)^{* * *}$ & $(-2.327)^{* *}$ \\
\hline \multirow{2}{*}{ SIZE } & 0.205 & 0.204 & 0.203 & 0.203 \\
\hline & $(8.903)^{* * *}$ & $(8.706)^{* * *}$ & $(9.374) * * *$ & $(9.321)^{* * *}$ \\
\hline \multirow{2}{*}{$T B Q L$} & -0.080 & -0.076 & -0.076 & -0.075 \\
\hline & $(-1.555)$ & $(-1.492)$ & $(-1.463)$ & $(-1.434)$ \\
\hline \multirow{2}{*}{ LEV } & 0.431 & 0.449 & 0.387 & 0.387 \\
\hline & $(2.956)^{* * *}$ & $(3.043)^{* * *}$ & $(2.373)^{* * *}$ & $(2.378)^{* *}$ \\
\hline \multirow{2}{*}{$V O L$} & -0.140 & -0.141 & -0.119 & -0.121 \\
\hline & $(-1.501)$ & $(-1.492)$ & $(-1.289)$ & $(-1.307)$ \\
\hline \multirow{2}{*}{ BETA } & 0.429 & 0.431 & 0.426 & 0.424 \\
\hline & $(4.263)^{* * *}$ & $(4.262)^{* * *}$ & $(4.286)^{* * *}$ & $(4.312)^{* * *}$ \\
\hline \multirow{2}{*}{ STDROA } & 0.421 & 0.414 & 0.422 & 0.410 \\
\hline & $(1.489)$ & $(1.492)$ & $(1.474)$ & $(1.398)$ \\
\hline \multirow{2}{*}{$F O R$} & 0.413 & 0.419 & 0.382 & 0.383 \\
\hline & $(2.284)^{* *}$ & $(2.329)^{* *}$ & $(1.942)^{*}$ & $(1.939)^{*}$ \\
\hline \multirow{2}{*}{ MTB } & -0.071 & -0.072 & -0.067 & -0.067 \\
\hline & $(-2.017)^{* *}$ & $(-2.044) * *$ & $(-1.926)^{*}$ & $(-1.923) *$ \\
\hline \multirow{2}{*}{ TRADING } & 0.010 & 0.010 & 0.009 & 0.009 \\
\hline & $(1.545)$ & $(1.514)$ & $(1.232)$ & $(1.246)$ \\
\hline \multirow{2}{*}{$P N$} & -0.038 & -0.041 & -0.015 & -0.014 \\
\hline & $(-1.236)$ & $(-1.374)$ & $(-0.446)$ & $(-0.406)$ \\
\hline \multirow{2}{*}{ Intercept } & -6.303 & -6.328 & -6.538 & -6.560 \\
\hline & $(-9.489) * * *$ & $(-9.411)^{* * *}$ & $(-10.160)^{* * *}$ & $(-10.106)^{* * *}$ \\
\hline Year & Included & Included & Included & Included \\
\hline$F$-value & 192.799 & 241.790 & 165.956 & 164.770 \\
\hline Adj. $R^{2}$ & 0.145 & 0.145 & 0.145 & 0.145 \\
\hline$n$ & 4,997 & 4,997 & 4,997 & 4,997 \\
\hline
\end{tabular}

Notes: The definitions of variables are defined in model (1). The notations ${ }^{* *}$, **, ${ }^{*}$ represent $p<0.01, p<0.05$, and $p<0.10$, respectively. Robust $t$-statistics are in parentheses below the coefficient.

Taken together, when the interaction term in the model is excluded, the synchronicity reduces after the IFRS adoption, which is in line with prior studies (Bissessur \& Hodgson, 2012; Beuslinck et al., 2009). However, the synchronicity increases in the concentrated industry in which firms are less likely to disclose firm-specific information before IFRS adoption. In addition, the results show that the homogeneity in accounting practices is not related to the synchronicity decrease after IFRS adoption.

The author interprets these results for hypotheses 1 and 2 that stock price synchronicity decreases greatly for firms in a concentrated industry after IFRS adoption, but homogeneity is not associated with the synchronicity changes in the post-adoption period.

Additionally, the analyses results with the sample excluding the IFRS adoption year (i.e., 2011) are presented in Table 4. These results are not different from the main results. The stock price synchronicity decreases after IFRS adoption for firms in the concentrated industry. Homogeneity continues to not have an incremental impact on synchronicity after IFRS adoption. 
Table 4. Additional test for Hypothesis 1: sample excluding IFRS adoption year

\begin{tabular}{|c|c|c|c|c|}
\hline \multirow{2}{*}{ Variables } & \multicolumn{2}{|c|}{$I N D=C O N$} & \multicolumn{2}{|c|}{$I N D=H G N$} \\
\hline & Coeff. & $t$-value & Coeff. & $t$-value \\
\hline$I N D$ & -0.005 & $(-0.409)$ & 0.418 & $(1.966)^{*}$ \\
\hline IND*IFRS & -0.031 & $(-2.900) * * *$ & -0.204 & $(-0.823)$ \\
\hline IFRS & -0.010 & $(-0.114)$ & -0.176 & $(-2.118)^{* *}$ \\
\hline$S I Z E$ & 0.198 & $(8.565)^{* * *}$ & 0.198 & $(9.116)^{* * *}$ \\
\hline$T B Q L$ & -0.093 & $(1.685)^{*}$ & -0.090 & $(-1.603)$ \\
\hline LEV & 0.425 & $(2.877)^{* * *}$ & 0.374 & $(2.225)^{* *}$ \\
\hline$V O L$ & -0.144 & $(-1.565)$ & -0.126 & $(-1.388)$ \\
\hline BETA & 0.401 & $(3.963)^{* * *}$ & 0.394 & $(3.993)^{* * *}$ \\
\hline STDROA & 0.274 & $(0.975)$ & 0.261 & $(0.862)$ \\
\hline$F O R$ & 0.416 & $(2.240)^{* *}$ & 0.376 & $(1.831)^{*}$ \\
\hline MTB & -0.056 & $(-1.526)$ & -0.052 & $(-1.426)$ \\
\hline TRADING & 0.013 & $(1.807)^{*}$ & -0.012 & $(1.514)$ \\
\hline$P N$ & -0.052 & $(-1.653) *$ & -0.020 & $(-0.567)$ \\
\hline Intercept & -6.091 & $(9.151)^{* * *}$ & -6.436 & $(-9.748)^{* * *}$ \\
\hline Year & \multicolumn{2}{|c|}{ Included } & \multicolumn{2}{|c|}{ Included } \\
\hline$F$-value & \multicolumn{2}{|c|}{152.736} & \multicolumn{2}{|c|}{164.945} \\
\hline Adj. $R^{2}$ & \multicolumn{2}{|c|}{0.144} & \multicolumn{2}{|c|}{0.143} \\
\hline n & \multicolumn{2}{|c|}{4,492} & \multicolumn{2}{|c|}{4,492} \\
\hline
\end{tabular}

Notes: The definitions of variables are defined in model (1). The notations ${ }^{* * *},{ }^{* *},{ }^{*}$ represent $\mathrm{p}<0.01, \mathrm{p}<0.05$, and $\mathrm{p}<0.10$, respectively. Robust $\mathrm{t}$-statistics are in parentheses opposite the coefficient.

Several robustness tests are conducted for hypothesis 1 to ensure that the main results are not sensitive to the measurement of industry concentration. First, according to prior studies (Ali et al., 2014; Dhaliwal et al., 2014), the four (three)-firm ratios (CR4 or CR3) of an industry by summing of the market share of the largest four (three) firms in each industry are used. Second, private firms are considered in calculating market share. It is possible for market share calculated by only public firms to capture the industry concentration firms actually experience. To alleviate this potential bias of measurement error, the concentration was recalculated by including private firms. Third, three-digit KSIC is used for industry classification, because 2-digit KSIC classification may be considered excessively broad. The analyses results are presented in Table 5 and the results support the hypothesis 1.

Table 5. Robustness tests for hypothesis 1: re-measurement of industry concentration

\begin{tabular}{|c|c|c|c|c|}
\hline \multirow{2}{*}{ Variables } & Model (1): CR4 & Model (2): CR3 & $\begin{array}{l}\text { Model (3): 2-digit SIC, } \\
\text { incl. private firms }\end{array}$ & $\begin{array}{l}\text { Model (4): 3-digit SIC, } \\
\text { incl. private firms }\end{array}$ \\
\hline & $\begin{array}{c}\text { Coeff. } \\
(t \text {-value) }\end{array}$ & $\begin{array}{c}\text { Coeff. } \\
\text { (t-value) }\end{array}$ & $\begin{array}{c}\text { Coeff. } \\
(t \text {-value })\end{array}$ & $\begin{array}{c}\text { Coeff. } \\
\text { (t-value). }\end{array}$ \\
\hline \multirow{2}{*}{ CON } & -0.081 & -0.065 & -0.004 & -0.011 \\
\hline & $(-0.482)$ & $(-0.391)$ & $(-0.391)$ & $(-0.897)$ \\
\hline \multirow{2}{*}{$C O N * I F R S$} & -0.519 & -0.495 & -0.024 & -0.027 \\
\hline & $(-3.309)^{* * *}$ & $(-3.127)^{* * *}$ & $(-1.768)^{*}$ & $(-1.497)^{* *}$ \\
\hline \multirow{2}{*}{ IFRS } & 0.138 & 0.091 & -0.109 & -0.077 \\
\hline & $(1.229)$ & $(0.867)$ & $(-1.737)^{*}$ & $(-1.133)$ \\
\hline \multirow{2}{*}{ Intercept } & -6.067 & -6.074 & -6.181 & -6.141 \\
\hline & $(-9.313)^{* * *}$ & $(-9.131)^{* * *}$ & $(-9.174)^{* * *}$ & $(-8.905)^{* * *}$ \\
\hline Control variables & Included & Included & Included & Included \\
\hline Year & Included & Included & Included & Included \\
\hline$F$-value & 169.434 & 167.753 & 148.452 & 149.693 \\
\hline Adj. $R^{2}$ & 0.145 & 0.144 & 0.143 & 0.144 \\
\hline$n$ & 4,492 & 4,492 & 4,492 & 4,492 \\
\hline
\end{tabular}

Notes: The definitions of variables are defined in model (1). The notations ${ }^{* * *},{ }^{* *}$, ${ }^{*}$ represent $p<0.01, p<0.05$, and $p<0.10$, respectively. Robust $t$-statistics are in parentheses below the coefficient. 


\section{CONCLUSION}

It is examined whether the change in stock price synchronicity after IFRS adoption is different according to the industry concentration and homogeneity. First, it is analyzed whether the synchronicity reduction after IFRS adoption is associated with the level of industry concentration. Second, it is tested whether the synchronicity increase after IFRS adoption is larger for firms in the less homogeneous industry.

The author finds that when an industry is more concentrated, the synchronicity reduction after IFRS adoption is larger. This finding implies that the increased firm-specific information disclosure required by IFRS improves the earnings quality of the firms in concentrated industries whose earnings quality is considered low in the pre-adoption period. The synchronicity changes by the level of homogeneity are not observed, implying that no evident comparability improvement is observed after IFRS adoption.

This paper contributes to prior studies in several ways. By focusing on industry characteristics, the author extends the literature on stock price synchronicity and the impact of IFRS adoption. With industry concentration and homogeneity, it is shown that the earnings quality improvement effect is more evident than the enhanced comparability effect, providing that IFRS adoption facilitates investors' valuation of firm-specific information from focal firms.

\section{REFERENCES}

1. Ali, A., Klasa, S., \& Yeung, E. (2014). Industry Concentration and Corporate Disclosure Policy. Journal of Accounting and Economics, 58(2-3), 240-264. https://doi.org/10.1016/j.jacceco.2014.08.004

2. Barth, M. (2006). Including Estimates of the Future in Today's Financial Statements. Accounting Horizon, 20(3), 271285. https://doi.org/10.2308/ acch.2006.20.3.271

3. Barth, M. E., Landsman, W. R., \& Lang, M. H. (2008). International accounting standards and accounting quality. Journal of Accounting Research, 46(3), 467-498. https://doi.org/10.1111/ j.1475-679X.2008.00287.x

4. Beuslinck, C., Joos, P., Khurana, I. K., \& Van der Meulen, S. (2009). Mandatory IFRS Reporting and Stock Price Informativeness (Working Paper). Retrieved from https://papers.ssrn.com/sol3/papers.cfm?abstract_id $=1381242$

5. Bissessur, S., \& Hodgson, A. (2012). Stock Market Synchronicity - an Alternative Approach to Assessing the Information Impact of Australian
IFRS. Accounting and Finance, 52, 187-212. https://doi.org/10.1111/ j.1467-629X.2010.00388.x

6. Brochet, F., Jaolinzer, A. D., \& Riedl, E. J. (2013). Mandatory IFRS adoption and financial statement comparability. Contemporary Accounting Research, 30(4), 1373-1400. https://doi.org/10.1111/19113846.12002

7. Cairney, T. D., \& Young, G. R. (2006). Homogeneous industries and auditor specialization: An indication of production economics. Auditing: A Journal of Practice and Theory, 25(1), 49-67. https://doi.org/10.2308/ aud.2006.25.1.49

8. Daske, H., Hail, L., Leuz, C., \& Verdi, R. (2013). Adopting a label: Heterogeneity in the economic consequences around IAS/IFRS adoptions. Journal of Accounting Research, 51(3), 495-547. https:// doi.org/10.1111/1475-679X.12005

9. Dechow, P., Ge, W., \& Schrand, C. (2010). Understanding Earnings Quality: A Review of the Proxies, Their Determinants and Their Consequences. Journal of Accounting and Economics, 50(2-3),
344-401. http://doi.org/10.1016/j. jacceco.2010.09.001

10. DeFond, M., Hu, X., Hung, M., \& Li, S. (2011). The Impact of Mandatory IFRS Adoption on Foreign Mutual Fund Ownership: The Role of Comparability. Journal of Accounting and Economics, 51(3), 240-258. https://doi. org/10.1016/j.jacceco.2011.02.001

11. De Franco G., Kothari, S. P., \& Verdi, S. (2011). The Benefits of Financial Statement Comparability. Journal of Accounting Research, 49(4), 895-931. https://doi.org/10.1111/ j.1475-679X.2011.00415.x

12. Dhaliwal, D., Huang, S., Khurana, I. K., \& Pereira, R. (2014). Product Market Competition and Conditional Conservatism. Review of Accounting Studies, 19(4), 13091345. https://doi.org/10.1007/ s11142-013-9267-2

13. Durnev, A., Morck, R., Yeung, B., \& Zarowin, P. (2003). Does Greater Firm-specific Return Variation Mean More or Less Informed Stock Pricing? Journal of Accounting Research, 41(5), 797-836. https://doi.org/10.1046/ j.1475-679X.2003.00124.x 
14. Dye, R. A., \& Sridhar, S. S. (2004). Reliability-relevance trade-offs and the efficiency of aggregation. Journal of Accounting Research, 42(1), 51-88. https://doi.org/10.1111/j.1475679X.2004.00129.x

15. Ferreira, M., \& Laux, P. (2007) Corporate Governance, Idiosyncratic Risk, and Information Flow. The Journal of Finance, 62(2), 951-989. https://doi.org/10.1111/j.15406261.2007.01228.x

16. Ha, S. T., Cho, S. P., \& Cho, J. H. (2016). Comparison of Accounting Quality of Firms between Korea and the US after IFRS adoption. Korean Accounting information Review, 34(2), 27-51.

17. Horton, J., Serafeim, G., \& Serafeim, I. (2013). Does mandatory IFRS adoption improve the information environment? Contemporary accounting research, 30(1), 388-423. https://doi.org/10.1111/j.19113846.2012.01159.x

18. International Accounting Standards Boards (2010). The Conceptual Framework for Financial Reporting. Chapter 1. The Objective of General Purpose of Financial Reporting, and Chapter 2. Qualitative Characteristics of Useful Financial Information. IASB, London.
19. Kim, J. B., \& Shi, H. (2012). IFRS Reporting, Firm-specific Information Flows, and Institutional Environments: International Evidence. Review of Accounting Studies, 17(3), 474-517. https://doi.org/10.1007/s11142012-9190-y

20. Leuz, C., \& Wysocki, P. D. (2016). The Economics of Disclosure and Financial Reporting Regulation: Evidence and Suggestions for Future Research. Journal of Accounting Research, 54(2), 525622. https://doi.org/10.1111/1475679X.12115

21. Morck, R., Yeung, B., \& Yu, W. (2000). The Information Content of Stock Markets: Why Do Emerging Markets Have Synchronous Stock Price Movements? Journal of Financial Economics, 58(1-2), 215-260. https://doi.org/10.1016/S0304405X(00)00071-4

22. Peterson, K., Schmardebeck, R., \& Wilks, T. J. (2015). The Earnings Quality and Information Processing Effects of Accounting Consistency. The Accounting Review, 90(6), 2483-2514. https:// doi.org/10.2308/accr-51048

23. Piotroski, J., \& Roulstone, D. (2004). The Influence of Analysts, Institutional Investors, and Insiders on the Incorporation of Market, Industry, and Firmspecific Information into Stock Prices. The Accounting Review, 79(4), 1119-1151. https://doi. org/10.2308/accr.2004.79.4.1119

24. Roll, R. (1988). R2. Journal of Finance, 43, 541-566.

25. Schipper, K. (2005). The Introduction of International Accounting Standards in European: Implications for International Convergence. European Accounting Review, 14(1), 101-126. https:// doi.org/10.1080/09638180420003 38013

26. Shin, S., \& Choi, K. (2013). The Effect of K-IFRS Adoption on Information Asymmetry and Stock Price Synchronicity (Working Paper). Sungkyunkwan University.

27. Wang, J. W., \& Yu, W. W. (2015). The Information content of stock prices, legal Environments, and accounting standards: International evidence. European Accounting Review, 24(3), 471-493. https://doi.org/10.1080/09638180.2 014.977802

28. Yen, J. C., Li, S. H., \& Chen, K. T. (2016). Product Market Competition and Firms' Narrative Disclosures: Evidence from Risk Factor Disclosures. AsiaPacific Journal of Accounting and Economics, 23(1), 43-74. https:// doi.org/10.1080/16081625.2014.1 003569 